\title{
ORIGINALS
}

\section{Glucagon Levels in Normal and Diabetic Subjects: Use of a Specific Immunoabsorbent for Glucagon Radioimmunoassay}

\author{
F.P. Alford, S. R. Bloom and J.D.N. Nabarro \\ Cobbold Laboratories, Middlesex Hospital Medical School, London, England
}

\begin{abstract}
Summary. Non-specific plasma effects may produce major errors in the estimation of true plasma pancreatic glucagon concentrations by radioimmunoassay. This has been circumvented by the production of glucagon-free plasma for each individual investigated, by means of glucagon antibody, coupled to sepharose beads. True fasting pancreatic glucagon levels (mean $\pm \mathrm{SEM})$ in 18 healthy subjects $(24 \pm 3 \mathrm{pg} / \mathrm{ml})$ were significantly lower $(\mathrm{p}<0.005)$ than in 10 non-ketotic non-obese diabetics $(38 \pm 3 \mathrm{pg} / \mathrm{ml})$. It is suggested that, in the presence of decreased insulin-effect in the diabetic, this $55 \%$ glucagon elevation in diabetics may be of biological importance and contribute to the fasting hyperglycaemia.
\end{abstract}

Key words: Pancreatic-glucagon, radioimmunoassay, glucagon-free plasma, glucagon-antibody coupled sepharose, fasting levels, normals, diabetics.

Current radioimmunoassays for plasma pancreatic glucagon are still unreliable $[1,2,3]$. A major source of error is the quantitative interference by nonspecific factors known to be present in plasma [3, 4]. These have been shown to have a particularly important influence on the apparent glucagon content of fasting human plasma [4]. The presence of these random interfering factors makes it essential that conditions in assay tubes for the unknown plasma sample and the pancreatic glucagon standards are identical. Only this will enable genuine hormone concentrations to be measured in the unknown plasma samples. The failure to achieve this ideal in most current assays and the variability of such interference in different assays probably accounts for the big discrepancies reported in the literature for fasting levels in diabetic subjects of pancreatic glucagon, which has been quoted as low [5], normal $[4,6,7,8]$, or raised $[9,10,11]$. In order to circumvent the problem, a technique has been developed whereby the glucagon content of each plasma is measured against a standard curve made up in an aliquot of the same plasma, made free of glucagon by prior extraction with a specific glucagon immunoabsorbent.

\section{Materials and Methods}

\section{Preparation of Antibody Sepharose Complex}

Bulk antisera were prepared in sheep by 3 monthly immunization with porcine glucagon coupled to albumin by carbodiimide condensation [12], and emulsified with complete Freund's adjuvant prior to injection. The antisera produced reacted both with pancreatic glucagon and enteroglucagon (synonymous with gut glucagon and glucagon-like immunoreactivity of intestinal origin, or GLI) as indicated by full displacement of labelled pancreatic glucagon from the antibody with both pancreatic glucagon standards and enteroglucagon containing intestinal extracts [13]. The antisera did not cross-react with other gut hormones. A globulin concentrate was prepared by ammonium sulphate precipitation, redissolved in $1 \mathrm{ml}$ of $0.1 \mathrm{M}$ bicarbonate $-0.14 \mathrm{M} \mathrm{NaCl}, \mathrm{pH} 8.0$ buffer and, after extensive dialysis, coupled to cyanogen bromide activated sepharose $4 \mathrm{~B}$ beads (Pharmacia, Uppsala, Sweden) [13]. The globulin $(80 \mathrm{mg})$ was coupled to $20 \mathrm{ml}$ (wet volume) activated sepharose beads by mixing for $15 \mathrm{~h}$ at $4^{\circ} \mathrm{C}$. The antibody complexed sepharose was then washed alternatively with the bicarbonate-saline buffer (2L) and distilled water (2L) and unreacted cyanogen bromide groups were blocked by $2 \mathrm{~h}$ incubation with $200 \mathrm{ml} 1 \mathrm{M}$ 


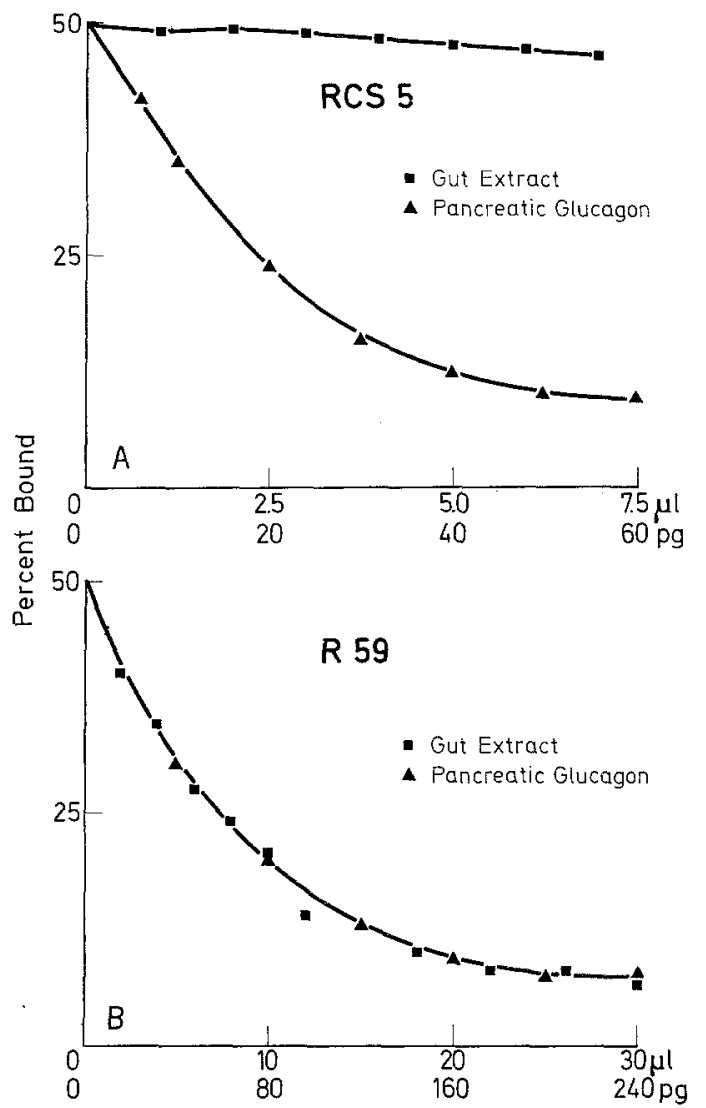

Fig. $1 \mathrm{~A}$ and $\mathrm{B}$. Validation of specificities of the (A) glucagon antibody-RCS5, and the (B) antibody R59. A Comparison of displacements of ${ }^{125} \mathrm{I}$-glucagon by porcine pancreatic glucagon standards and a gut extract containing glucagon-like material, employing antiserum RCS5. B Demonstration of parallel displacements of ${ }^{125}$ I-glucagon by pancreatic glucagon and gut extract, employing antiserum R59

ethanolamine $(\mathrm{pH} 8.0)$. Immediately before use the antibody beads were washed extensively with alternating $0.5 \mathrm{M}$ acetate $-0.5 \mathrm{M} \mathrm{NaCl}(\mathrm{pH} 4.0)$ and bicarbonate $/ \mathrm{NaCl}$ ( $\mathrm{pH} 8.0$ ) buffers. Activity was maintained on storage at $4^{\circ}$ for at least 7 months.

\section{Affinity Chromatography}

$100 \mu \mathrm{l}$ of $1: 1$, beads: bicarbonate $/ \mathrm{NaCl}(\mathrm{pH} 8.0)$ buffer, were dispensed into $2 \mathrm{ml}$ plasma samples, or test solutions, mixed by slow, end over end agitation for $2 \mathrm{~h}$ at room temperature, and separated by centrifugation. Buffer solutions contained $2 \%$ human serum albumin (HSA) and all plasma and test solutions contained 1,000 Kallekrein Inactivator Units (KIU) aprotinin per $\mathrm{ml}$. When it was desired to recover glucagon bound to beads, the pellet was mixed with $1 \mathrm{ml}$ of a $1 \% \mathrm{HSA}$ solution titrated to $\mathrm{pH} 1.5$ with $\mathrm{HCl}$, and gently mixed for $30 \mathrm{~min}$ at room temperature. After centrifugation the supernatant was separated and adjusted to $\mathrm{pH} 8.0$ with $0.1 \mathrm{M}$ ammonium hydroxide.

\section{Assay}

Plasma glucagon was measured by radioimmunoassay. Antisera were raised in rabbits similarly to sheep (above). One antiserum (RCS5) was found to be specific for pancreatic glucagon $[14,15]$ (C terminal reacting), and did not cross react significantly with crude or purified extracts of whole human bowel. Another antiserum (R59) cross reacted to a high degree with intestinal extracts, which contained enteroglucagon, and displayed parallel affinity for the pancreatic glucagon standards and intestinal extracts (Fig. 1). This antiserum (R59) was used to measure total plasma glucagon, and plasma enteroglucagon content was calculated by subtraction of the pancreatic (RCS5 determined) glucagon concentration. Neither antisera reacted with gastric inhibitory peptide, secretin or vasoactive intestinal peptide (VIP). ${ }^{125}$ I-glucagon tracer was prepared by a modified chloramine $T$ technique [16]. Approximately $1 / 20$ th of the glucagon was iodinated and the monoiodinated glucagon component purified out by high resolution ion exchange chromatography on a QAE sephadex column at $\mathrm{pH} 8.5$ [16]. The ${ }^{125}$ I-glucagon thus prepared was stable for at least four months and had a

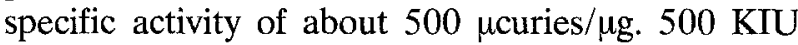
aprotinin was employed in each assay tube. The duplicate $0.8 \mathrm{ml}$ assay tubes contained $200 \mu \mathrm{l}$ of plasma and $10 \mathrm{pg}$ of ${ }^{125} \mathrm{I}$-glucagon. After incubation for five days at $4^{\circ} \mathrm{C}$ antibody-bound radioactivity was separated from free hormone by addition of dextran-coated charcoal [17]. Each individual's plasma sample was assayed against glucagon standards (MRC 69/104) made up in his own glucagon-free plasma, prepared by the sepharose bead technique detailed above. The assays were thus set up with standard curves in each individual's glucagon-free plasma and also with a standard curve made up in the laboratory "control" plasma prepared from pooled, time-expired blood bank plasma, which was effectively glucagon-free ${ }^{1}$. Using antiserum RCS5 (pancreatic glucagon specific) the assay could detect changes of $10 \mathrm{pg} / \mathrm{ml}$ between adjacent samples with $95 \%$ confidence. Intra and inter-assay reproducibility expressed as a coefficient of variation for a quality control plasma of $90 \mathrm{pg} / \mathrm{ml}$ was $7.8 \%(\mathrm{n}=22)$ and $14.9 \%(\mathrm{n}=9)$ respectively.

\footnotetext{
1 Whole blood was collected into sterile heparin (10 units $/ \mathrm{ml}$ ) without aprotinin, stored at $4^{\circ} \mathrm{C}$ for 2-3 weeks and separated. Aprotinin $(500 \mathrm{KIU} / \mathrm{ml})$ was then added to the plasma, which was aliquoted and frozen until the time of the assay. Only those plasmas that allowed maximum binding of tracer to charcoal, maximum binding of tracer to antibody and displayed the maximum displacement of tracer from antibody by the porcine pancreatic glucagon standards were used in assays. About one-third of the stored blood samples yielded suitable plasmas. A minimum of five of these were pooled and used in the assay standard curve and as control "zero" plasma
} 
Plasma insulin was measured by radioimmunoassay (using the Wellcome Reagents) and a charcoal separation procedure [17].

\section{Patients}

a. Plasma was collected from 4 healthy volunteers being infused with GHRIH (somatostatin) $13 \mu \mathrm{g} / \mathrm{min}$ as part of another study [18].

$b$. Three subjects were studied after glucagon stimulation, one with arginine infusion $(0.5 \mathrm{~g} / \mathrm{kg}$ for $30 \mathrm{~min})$ and two $45 \mathrm{~min}$ after ingestion of $8 \mathrm{oz}$ lean meat.

c. Ten non-ketotic non-obese (mean \pm SEM, $64.4 \pm$ $4 \mathrm{~kg}$ ) diabetic subjects (6 male and 4 female, aged 41-71 years) and eighteen healthy non-obese ( $60.5 \pm$ $2 \mathrm{~kg}$ ) control subjects (8 male and 10 female, aged 21-81 years) were investigated. The diabetic subjects had been treated by diet alone and none had previously been on oral hypoglycaemic agents or insulin therapy. The duration of diabetes varied from one month to four years (mean 1.4 years). The diagnosis was based on either a diabetic oral glucose tolerance test (fasting glucose $>6.6$ and $2 \mathrm{~h}$ value $>9.0$ $\mathrm{mmol} / \mathrm{L}$ ) or by random blood glucose in excess of 11.0 $\mathrm{mmol} / \mathrm{L}$. Mean blood glucose levels were $9.7 \pm 0.8$ at routine clinic visits, with a range of $5.6-12.8 \mathrm{mmol} / \mathrm{L}$. The dietary intake of control subjects and diabetics was assessed by a dietician on the day of the study. Control subjects consumed a mean of 2300 calories per day, with $240 \mathrm{~g}$ carbohydrate and $79 \mathrm{~g}$ protein. The diabetics consumed 1660 calories per day with $166 \mathrm{~g}$ carbohydrate and $68 \mathrm{~g}$ protein. Following an overnight $15 \mathrm{~h}$ fast, an indwelling needle was placed in an arm vein and after a 30 min rest period blood was taken for glucagon assays into heparinised tubes containing 1,000 KIU aprotinin $/ \mathrm{ml}$, immediately separated and stored at $-20^{\circ} \mathrm{C}$.

\section{Results}

\section{Properties of Antibody Sepharose Complex}

Time course at room temperature of binding of ${ }^{125} \mathrm{I}$ labelled glucagon $(100 \mathrm{pg})$ to the antibody-sepharose complex is shown in Figure 2A. Maximum binding $(89 \%)$ occurred by $1 \mathrm{~h}$ and therefore, in all subsequent experiments, samples (labelled or unlabelled hormone or plasma samples) were mixed with the antibody-sepharose complex for $2 \mathrm{~h}$. This figure also demonstrates (dotted line) that non-specific binding (tested by using ${ }^{125} \mathrm{I}$ gastrin and ${ }^{125} \mathrm{I}$ VIP) was always low, $5.2 \pm 2.0(\mathrm{SD}) \%$, in contrast to the specific binding of ${ }^{125}$ I glucagon of $89 \pm 1 \%(\mathrm{n}=10)$.
In the lower panel of Figure 2 is shown the time course of removal of ${ }^{125} \mathrm{I}$-glucagon previously bound to the antibody-sepharose bead complex (Fig. 1B). Using a $\mathrm{pH} 1.5 \mathrm{HCl} /$ water/aprotinin/HSA mixture, $91.5 \pm 0.5 \%$ was removed by $30 \mathrm{~min}$. The eluted ${ }^{125}$ I-glucagon possessed full immunoreactivity. Thus, following neutralisation of supernatant the back to $\mathrm{pH}$ 8.0 and re-exposure of this supernatant to fresh antibody-sepharose complex, $92 \pm 2.5 \%{ }^{125} \mathrm{I}$-glucagon rebound to the beads. Further, $88 \%$ of this neutralised supernatant, that is the ${ }^{125} \mathrm{I}$-glucagon-eluate, was bound in the presence of excess antibody, employing the standard glucagon immunoassay.

Control studies with the glucagon-sepharose beads were unable to detect any significant leaching of the antibody into the glucagon-free plasma under the conditions used. To test whether exposure of plasma to sepharose beads may itself introduce artefacts into the assay system, plasma glucagon concentrations were estimated in plasma prior to and following exposure to sepharose beads coupled to other gamma globulins, eg antiVIP, antisecretion and antigastrin sepharose beads. No change in glucagon values was observed.

Separate experiments with unlabelled pancreatic glucagon demonstrated that up to $4.5 \mathrm{ng}$ glucagon could be bound to $50 \mu \mathrm{l}$ wet volume of the antibodysepharose beads. The recovery of unlabelled pancreatic glucagon from the antibody-sepharose complex using the acid wash procedure was $109 \%(n=4)$.

\section{Radioimmunoassay Results}

a. GHRIH Study. The GHRIH induced fall in plasma glucagon levels was similar for both assay techniques (Fig. 3). Thus the mean \pm SEM basal and nadir were $25 \pm 6$ and $5 \pm 3 \mathrm{pg} / \mathrm{ml}$ for the standard assay and $25 \pm 6$ and $7 \pm 2 \mathrm{pg} / \mathrm{ml}$ for the sepharose bead assay.

b. Glucagon Stimulation Study. Following arginine or protein meal, similar rises of glucagon were observed for both assay techniques (Fig. 4). For arginine, basal and peak glucagon levels were 15 and $100 \mathrm{pg} / \mathrm{ml}$ respectively for the standard assay and 18 and 103 $\mathrm{pg} / \mathrm{ml}$ respectively for the sepharose bead assay. After the protein meal, similar results were obtained (Fig. 4).

c. Diabetic Study. Control subjects had a mean fasting glucagon of $22 \pm 3 \mathrm{pg} / \mathrm{ml}$ and the diabetics of $35 \pm 3$ $\mathrm{pg} / \mathrm{ml}$ employing the standard assay (Fig. 5). A similar mean difference between the two groups was observed with the sepharose bead assay (Controls: $24 \pm$ 3 versus diabetics: $38 \pm 3 \mathrm{pg} / \mathrm{ml}$ ). Plasma enteroglucagon and insulin concentrations were similar in 

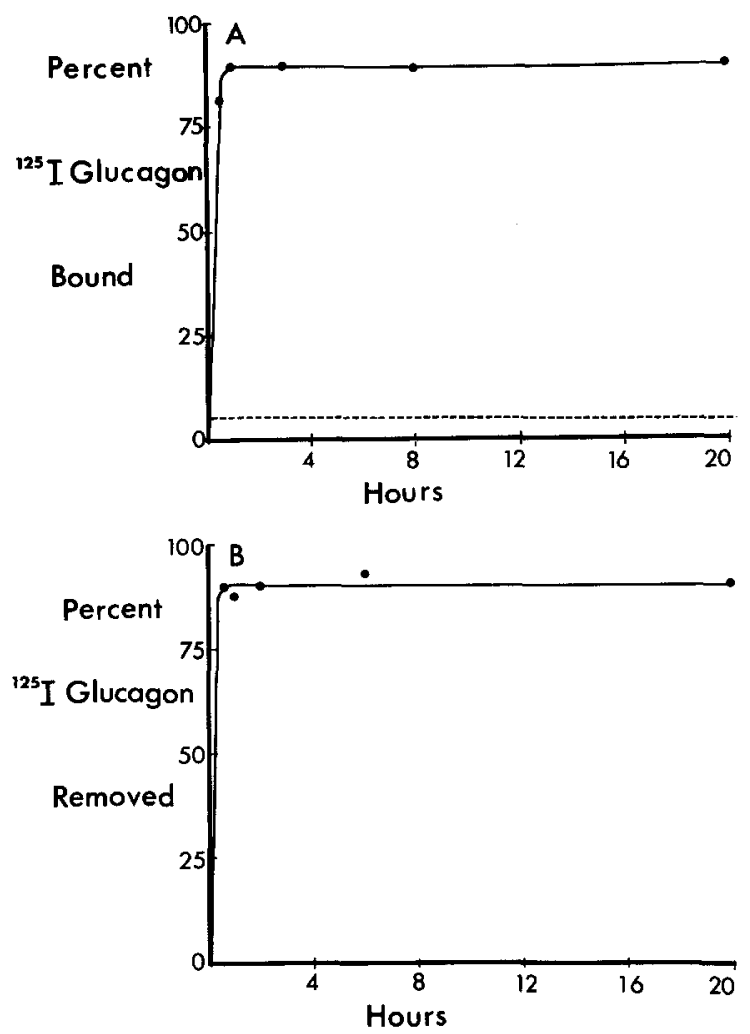

Fig. $2 \mathrm{~A}$ and $\mathbf{B}$. Validation of glucagon-antibody-sepharose-bead technique. Experiments were performed at room temperature. A Time course of binding of ${ }^{125}$ I-glucagon to $50 \mu \mathrm{l}$ wet volume of

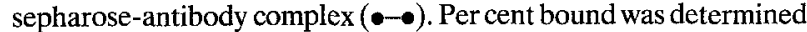
by expressing $\mathrm{cpm}$ bound to beads, as compared to total counts added. The dotted line represents non-specific counts bound, as measured with ${ }^{125} \mathrm{I}$-VIP and ${ }^{125} \mathrm{I}$-gastrin. B Time course of removal of ${ }^{125} \mathrm{I}$-glucagon by acid mixture of $\mathrm{HCl} / \mathrm{H}_{2} \mathrm{O} / 1 \% \mathrm{HSA} / 1 \%$ Aproti$\operatorname{nin}(\mathrm{pH} 1.5)(\bullet-\bullet)$. Per cent removed was expressed as cpm in the acid mixture supernate as compared to total counts on the beads prior to exposure to the acid mixture

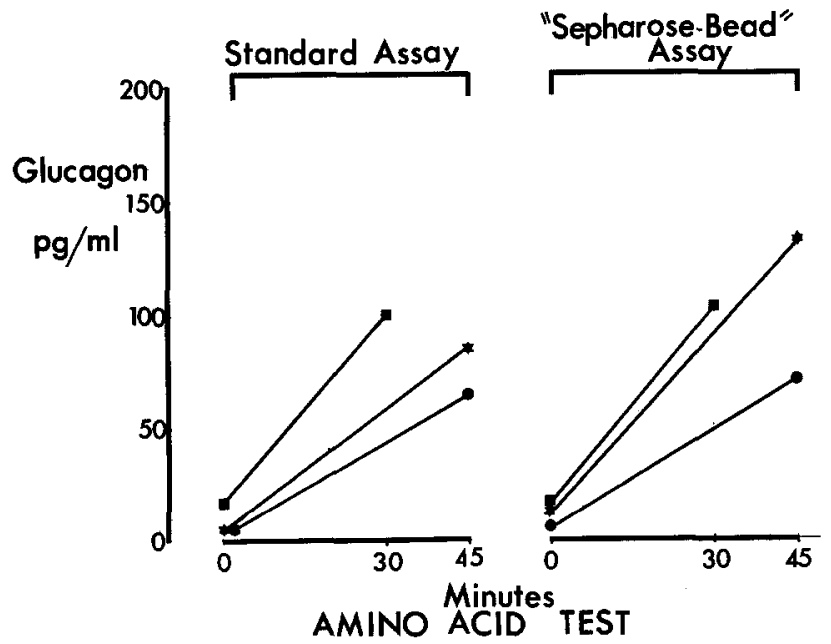

Fig. 4. Comparison of pancreatic glucagon concentrations obtained with the standard immunoassay and the "sepharose-bead" assay in three subjects, following an arginine $(0.5 \mathrm{gm} / \mathrm{kg})$ infusion ( $(--)$ ) or a high protein meal $(*-*, \bullet \bullet)$

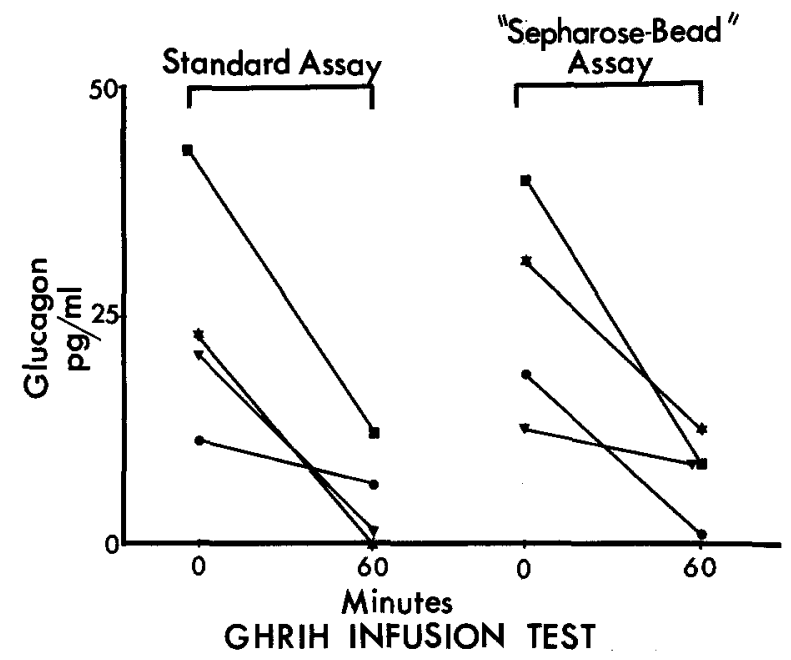

Fig. 3. Comparison of pancreatic glucagon concentrations obtained with the standard immunoassay and the "sepharose-bead" assay in four subjects infused for $60 \mathrm{~min}$ with GHRIH (13 $\mu \mathrm{g} / \mathrm{min})$

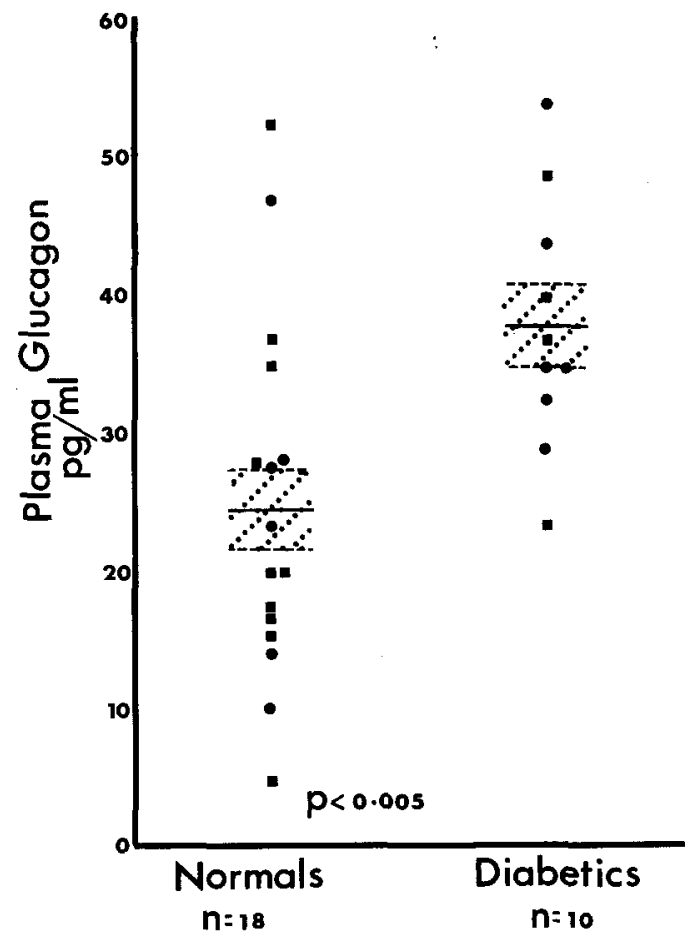

Fig. 5. Fasting plasma pancreatic glucagon concentrations in normal and diabetic subjects. The closed circles $(\bullet)$ and squares $(\boldsymbol{\bullet})$ represent male and female subjects and the solid and dotted lines represent mean \pm SEM respectively 
the two groups (Table 1). There was no correlation between fasting glucose and glucagon levels.

There was very little difference in all the above measurements between results read off the individual curve made up in the person's own glucagon-free plasma and results read off the standard curve employing pooled time-expired blood bank plasma ( $\mathrm{r} 0.93$ ). This correlation is depicted in Figure 6.

\section{Discussion}

True fasting levels of pancreatic glucagon in normal subjects are not known, wide variations of glucagon concentrations occurring between laboratories and between subjects within the same laboratory (3-11). The reasons for these variations are not clear but non-specific assay "interference factors" are important $[1,4]$. Weir and co-workers have recently demonstrated that this "interference factor" varies widely from subject to subject and may account for up to $100 \%$ of the "measured" basal glucagon concentration, employing the widely used antiserum of Unger, $30 \mathrm{~K}[4]$. This variability between plasma highlights the essential need for identical conditions in the standard and unknown plasma assay tubes. The results presented here show that an affinity chromatography technique, employing glucagon antibody coupled to sepharose beads provides a practical method to investigate the above problems. The technique is specific and reproducible. The antibody-sepharose bead complex is stable on prolonged storage and significant leaching of glucagon antibodies off the beads, in contrast to insulin coupled sepharose [19], is not a problem. Furthermore, since the technique produces a true "glucagon-free" plasma, a direct comparison between endogenous glucagon of the unknown plasma sample and the pancreatic glucagon standards is possible. These results also indicate that with antiserum RCS5, the differences between glucagon standards diluted in time-expired blood bank plasma and sepharose-bead plasma are small. Thus for routine assay purposes individual application of the sepharose-bead technique may not be required, but in specific circumstances where accurate true hormone concentrations are important, its use gives much greater validity.

Weir et al. found that the large and variable nonspecific assay interference factor with antiserum $30 \mathrm{~K}$ could be removed by prior extraction of the plasma sample with charcoal [4]. However, charcoal also removes from plasma many other proteins and small peptides, for example insulin, gastrin and growth hormones and results in the production of a "peptide free plasma". It is uncertain whether such charcoalised "plasmas" perform as true plasma in subsequent radioimmunoassays. Experience in this laboratory with charcoalised plasma has revealed inconsistent and unpredictable changes in their characteristics
Table 1. Mean \pm SEM of plasma enteroglucagon and insulin concentrations in control and diabetic groups

\begin{tabular}{lll}
\hline Group & $\begin{array}{l}\text { Glucagon } \\
\text { pg equiv/ml }\end{array}$ & $\begin{array}{l}\text { Insulin } \\
\mu \mathrm{U} / \mathrm{ml}\end{array}$ \\
\hline $\begin{array}{l}\text { Controls } \\
(\mathrm{n}=10)\end{array}$ & $143 \pm 32$ & $4.5 \pm 0.6$ \\
$\begin{array}{l}\text { Diabetics } \\
(\mathrm{n}=7)\end{array}$ & $126 \pm 36$ & $4.2 \pm 1.7$ \\
\hline
\end{tabular}

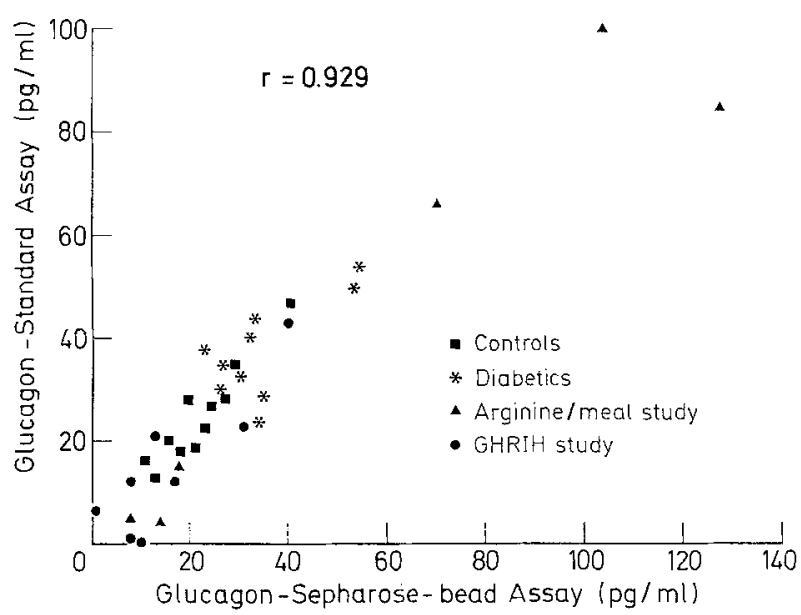

Fig. 6. Correlation between plasma pancreatic glucagon concentrations obtained with the standard as compared to the "sepharose-bead" assay. Samples from the four study groups have been combined for this analysis

(Bloom and Alford unpublished). On the other hand, exposure of plasma to the sepharose bead immunoabsorbent does not produce any detectable changes in the general characteristics of plasma or introduce new artefacts into the assay. The glucagon bead technique removes glucagon-like immunoreactive substances quite specifically (Fig. 2A).

The recent realisation that circulating pancreatic glucagon exists in several different sized molecular species with identical affinity for pancreatic glucagon specific antisera $[20,21]$ increases the need to exclude further complication from additional non-specific interference factors. The variable recoveries from gel columns makes quantitation, especially of low hormone levels, quite impossible. Thus the present affinity chromatographic technique offers a possible way to avoid some of these difficulties. Clearly the production of unmodified but specific "hormone" free plasma is a routine need of most current immunoassays and the immunoabsorbent method therefore has a wide application.

Fasting levels of pancreatic glucagon in this assay system were much lower than those reported from other laboratories $[6,7,10,11,22]$. The levels are similar to the charcoal-corrected values obtained by Weir and associates [4], however, suggesting that 
"true" fasting levels of pancreatic glucagon are lower than previously accepted values. Obviously, these absolute values are subject to the accepted limitations of radioimmunoassays. Of considerable importance is the significantly greater fasting levels of pancreatic glucagon in the non-ketotic non-obese diabetic subjects which were $14 \mathrm{pg} / \mathrm{ml}$ higher than the control subjects. This is not likely to be the result of any dietary difference as only extremes of protein or carbohydrate intake influence basal glucagons [23]. Absolute differences of this magnitude between diabetics and controls have been reported by others $[9,10,11]$. However, overall values for both control and diabetic subjects are much lower than those reported by other laboratories using less specific assay methods. The actual percentage difference is, therefore, considerably greater, representing some $55 \%$. Since the metabolic clearance rate of glucagon is not decreased in diabetic subjects [24], this increase probably represents a true excess secretion of pancreatic glucagon in the diabetics. A difference of this magnitude may be of considerable biological importance in diabetes, especially in the presence of the postulated decreased "effectiveness" of circulating insulin in these subjects [25].

Acknowledgments. The untiring efforts of Mrs. E. Brocklehurst are gratefully acknowledged. FPA was in receipt of Astor Fellowship, Middlesex Hospital Medical School, and the Gordon-Taylor and Sheppard Lowe Scholarships, University of Melbourne, Australia. SRB was an MRC Research Fellow. This study was performed as part of work undertaken by the British Diabetic Association Research Group at The Middlesex Hospital and Medical School. This study was carried out with the kind co-operation of Dr. A. Barnes and Dr. A. Bloom of the Whittington Hospital, London.

\section{References}

1. Heding, L.G.: Radioimmunological determination of pancreatic and gut glucagon in plasma. Diabetologia 7, 10-19 (1971)

2. Luyckx, A.S.: Immunoassays for glucagon. In: Glucagon: molecular physiology, clinical and therapeutic implications, (eds. P.J. Lefebvre, R.H. Unger), pp. 285-298. Oxford and New York: Permagon Press 1972

3. Unger, R.H., Eisentraut, A.M.: Etudes recentée sûr la physiologie du glucagon. In: Journées annuelles de Diabétologie de I'Hôtel-Dieu, pp. 7-18. Paris: Ed. Médicales Flammarion 1967

4. Weir, G.C., Knowlton, S.D., Martin, D. B.: High molecular weight glucagon-like immunoreactivity in plasma. J. clin. Endocr. 40, 296-302 (1975)

5. Buchanan, K.D., McCarroll, A.M.: Abnormalities of glucagon metabolism in untreated diabetes mellitus. Lancet $1972 \mathrm{I}$, 1394-1395

6. Muller, W.A., Faloona, G.R., Aguilar-Parada, E., Unger, R.H.: Abnormal alpha cell function in diabetes: response to carbohydrate and protein ingestion. New Engl. J. Med. 283, 109-115 (1970)
7. Gerich, J.E., Langlois, M., Noacco, C., Karam, J.H., Forsham, P.H.: Lack of glucagon response to hypoglycaemia in diabetes: evidence for an intrinsic pancreatic alpha cell defect. Science 182, 171-173 (1973)

8. Unger, R.H., Aguilar-Parada, E., Muller, W.A., Eisentraut, A.M.: Studies of pancreatic alpha cell function in normal and diabetic subjects. J. clin. Invest. 49, 837-848 (1970)

9. Aguilar-Parade, E., Eisentraut, A.M., Unger, R.H.: Pancreatic glucagon secretion in normal and diabetic subjects. Amer. J. med. Sci. 257, 415-419 (1969)

10. Heding, L. G., Rasmussen, S.M.: Determination of pancreatic and gut glucagon-like immunoreactivity in normal and diabetic subjects. Diabetologia 8, 408-411 (1972)

11. Day, J.L., Anderson, J.: Abnormalities of glucagon metabolism in diabetes mellitus. Clin. Endocr. 2, 211-217 (1973)

12. Ozawa, H.: Reaction of insulin with ethyl glycinate and l-ethyl -3- (3-dimethylamino propyl) carbodiimide. Biochemistry (Easton) 9, 2158-2163 (1970)

13. Murphy, R.F., Buchanan, K.D., Elmore, D.I.: Isolation of glucagon-like immunoreactivity of gut by affinity chromatography on antiglucagon antibodies coupled to Sepharose 4B. Biochim. biophys. Acta (Amst.) 303, 118-127 (1973)

14. Barnes, A.J., Bloom, S. R.: Pancreatectomised man: a model for diabetes without glucagon. Lancet 1976 I, 219-222

15. Thomson, J.P.S., Bloom, S.R.: Plasma enteroglucagon and plasma volume change after gastric surgery. Clin. Sci. Mol. Med. 51, 177-183 (1976)

16. Jorgensen, K.H., Larsen, U. D.: Purification of ${ }^{125}$ I-glucagon by anion exchange chromatography. Horm. Metab. Res. 4, 4223-4224 (1972)

17. Albano, J.D.M., Ekins, R.P., Maritz, G., Turner, R.C.: A sensitive precise radioimmunoassay of serum insulin relying on charcoal separation of bound and free hormone moieties. Acta endocr. (Kbh.) 70, 487-509 (1972)

18. Alford, F.P., Bloom, S.R., Nabarro, J.D.N., Hall, R.G.M., Coy, D.H., Kastin, A.J., Schally, A.V.: Glucagon control of fasting glucose in man. Lancet 1974 II, 974-976

19. Kolb, H.J., Renner, R., Hepp, K.D., Weiss, L., Wieland, O.H.: Re-evaluation of sepharose-insulin as a tool for the study of insulin action. Proc. nat. Acad. Sci. (Wash.) 72, 248-252 (1975)

20. Kuku, S.F., Zeidler, A., Emmanouel, D.S., Katz, A.I., Rubenstein, A.H.: Heterogeneity of plasma glucagon: patterns in patients with chronic renal failure and diabetes. J. clin. Endocr. 42, 173-176 (1976)

21. Chisholm, D.J., Alford, F.P., Harewood, M., Findlay, D., Gray, B.: The nature and biological activity of extra-pancreatic immuno-reactive glucagon in pancreatectomised cats. Proc. Endocr. Soc. Australia 19, 9 (1976)

22. Henquin, J.C., Malvaux, P., Lambert, A.E.: Glucagon immunoassay using polyethylene glycol to precipitate antibodybound hormone. Diabetologia 10, 61-68 (1974)

23. Ahmed, M., Lamusga, R.F., Anderson, N.T., Nuttall, F.Q.: Effect of diet composition on plasma glucagon concentration. Diabetes 25 (Suppl. 1), 77 (1976)

24. Alford, F.P., Bloom, S.R., Nabarro, J.D.N.: Glucagon metabolism in man. Studies on the metabolic clearance rate and the plasma acute disappearance time of glucagon in normal and diabetic subjects. J. clin. Endocr. 42, 830-838 (1976)

25. Reaven, G.M., Bernstein, R., Davis, B., Olefsky, J.M.: Nonketotic diabetes mellitus: insulin deficiency or insulin resistance? Amer. J. Med. 60, 80-88 (1976)

Received: May 4, 1976, and in revised form: September 27, 1976

Dr. F.P. Alford

Endocrine Unit

St. Vincent's Hospital

Fitzroy, 3067 Vic.

Australia 